\section{Parameter Menentukan Perbuatan Wanprestasi Dan Penipuan Dari Suatu Perjanjian}

Oleh:

Azhari AR.

\section{Abstract}

Agreement is made legally binding for the makers and the parties are obliged to fulfill it. In the practice of daily life, it is not uncommon for contract actors who do not carry out their obligations; they are being prosecuted by creditors through criminal law by referring to article 378 of the Criminal Code so that there seems to be a similarity between the default legal figure and fraud in an agreement, whereas in the regulation both of these are governed by different laws. Default is regulated in the Civil Code while fraud is regulated in the Criminal Code. The problem in this paper is what is the parameter or measure to determine the legal acts of default and criminal act of fraud.

Distinguishing parameter between default and fraud is on the default which is seen from the objective and subjective factors of good faith, while the criminal act of fraud is motivated by evil intentions (mens rea) to have an object (items) belonging to someone else with the parameters of subjective and objective elements. In the future, law practitioners and academics should be able to separate explicitly to settle dispute agreements that contain defaults and criminal act of fraud.

\section{Abstrak}

Perjanjian yang dibuat secara sah mengikat bagi para pembuatnya, dan para pihak berkewajiban untuk memenuhinya. Dalam praktik kehidupan sehari-hari tidak jarang pelaku kontrak yang tidak melaksanakan kewajibannya oleh kreditur dituntut melalui hukum pidana dengan merujuk pasal 378 KUHPidana sehingga terkesan ada kesamaan figure hukum wanprestasi dengan tindak pidana penipuan dalam suatu perjanjian, padahal dalam pengaturannya kedua hal tersebut diatur pada hukum yang berbeda wanprestasi diatur dalam KUHPerdata sedangkan tindak pidanan penipuan diatur dalam KUHPidana yang menjadi permasalahan dalam tulisan ini adalah apakah yang menjadi parameter atau ukuran untuk menentukan perbuatan hukum wanprestasi dan tindak pidana penipuan.

Parameter pembeda wanprestasi dengan tindak pidana penipuan adalah pada wanprestasi dilihat dari factor itikad baik secara objektif maupun subjektif, sedangkan pada tindak pidana penipuan dilatarbelakangi niat jahat (mens rea) dalam memiliki suatu benda (barang) milik orang lain dengan parameter unsur subjektif dan objektif. Untuk kedepan kepada para praktisi hukum dan akademisi hendaknya dapat memisahkan secara tegas untuk menyelesaikan sengketa perjanjian yang di dalamnya mengandung wanprestasi dan tindak pidana penipuan

\section{PENDAHULUAN}

\section{A. Latar Belakang}

Aristoteles menyatakan manusia ditakdirkan sebagai makhluk sosial, atau yang dalam bahasa latinnya adalah "zoon politicon". Manusia tidak dapat dipikirkan sebagai makhluk yang hidup sama sekali terasing dan terpencil dari sesama manusia. Sebaliknya manusia harus selalu hidup dalam ikatan kelompok, ikatan golongan, ikatan kerukunan ${ }^{1}$. Manusia sebagai makhluk sosial dan sekaligus merupakan subjek hukumsaling berinteraksi untuk memenuhi kebutuhan hidupnya.

Interaksi minimal melibatkan dua pihak, dalam arti masing-masing pihak berkeinginan untuk memperoleh manfaat atau keuntungan. Hal ini menyebabkan kedua belah pihak menjadi saling terikat karenanya, dengan demikian yang dilakukan segenap kelompok sudah barang tentu adanya suatu ikatan-ikatan yang muncul memerlukan aturan. Sebab jika tidak ada aturan

${ }^{1}$ Achmad Ihsan, Hukum Perdata

PT.Pembimbing Masa, Jakarta, 1967, h. 1 
Media Komunikasi dan Informasi Hukum dan Masyarakat

yang jelas, akan menimbulkan benturan kepentingan yang dapat mengakibatkan ketidakteraturan dalam kehidupan

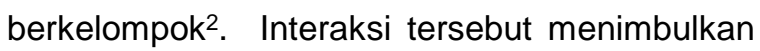
ikatan di antara mereka, jelas kegiatan ini bersifat privat. $^{3}$ Untuk itu hukum dibutuhkan untuk mengatur interaksi sesama manusia dalam kehidupan bermasyarakat

Dalam kajian ilmu hukum menurut isinya, hukum dapat dibagi menjadi hukum privat (hukum sipil) dan hukum publik (hukum negara) ${ }^{4}$. Hukum privat mengatur antara orang yang satu dengan orang yang lain, dengan menitikberatkan pada kepentingan perorangan ${ }^{5}$. Dalam arti luas, hukum privat meliputi hukum perdata dan hukum dagang, sedangkan dalam arti sempit, hukum privat hanya terdiri dari hukum perdata. ${ }^{6}$. Hukum publik adalah hukum yang mengatur hubungan antara negara dengan alat-alat perlengkapan atau hubungan antara negara dengan warganegaranya ${ }^{7}$.Adanya pembedaan hukum publik hukum dengan hukum privat menjadi permasalahan dalam praktek di pengadilan khususnya terkait dengan kebebasan sebagai hak asasi manusia.

Lamintang mensinyalir sering terjadi di kota-kota besar, di tempat yang sering diadakan perjanjian-perjanjian jual beli barang, perjanjian hutang piutang, dan lain-lain, dimana para penjual atau orang yang berpiutang sering kali datang kepada penyelidik atau penyidik melaporkan tentang dilakukan penggelapan melanggar Pasal 372 KUHPidana atau tentang dilakukannya suatu frelssentrekkerij melanggar Pasal 379a KUHPidana oleh seorang yang

${ }^{2}$ Yahman, Karakteristik Wanprestasi \& Tindak Pidana Penipuan yang lahir dari Hubungan Kontraktual, Prenadamedia Group, Jakarta 2014, h. 1

${ }^{3} \mathrm{M}$. Isnaeni, Makalah Disampaikan Dalam Pelatihan Hukum Perikatan Bagi Dosen Praktisi, Fakultas Hukum Universitas Airlangga Surabaya, 6 -7 September 2006, h. 3

${ }^{4}$ C.S.T. Kansil, Pengantar IImu Hukum. Jakarta : Balai Pustaka, 2002, h. 46

${ }^{5}$ Ibid.
${ }^{6}$ Ibid.
${ }^{7}$ Ibid. berutang, padahal maksud yang sebenarnya dari pelapor adalah agar orang yang dilaporkan itu kemudian mau membayar hutang-hutangnya setelah ia dimasukkan kedalam tahanan oleh penyidik. ${ }^{8}$

Hal senada Yahman menerangkan, tidak jarang dalam penyelesaian masalah yang berkaitan dengan ingkar janji, yang pada dasarnya merupakan lingkup hukum privat (hukum perdata), dibawa ke ranah pidana dengan menggunakan Pasal 378 Kitab UndangUndang Hukum Pidana (selanjutnya disingkat KUHP) tentang penipuan sebagai penyelesaian dari masalah ingkar janji tersebut. Dalam praktik penegakan hukum berkenaan dengan kontrak, untuk segera mendapatkan haknya seseorang kerap mencari jalan pintas, salah satunya dengan cara melaporkan kepada pihak kepolisian (Perkara Pidana). Argumentasi sederhana yang dikemukakan, yaitu supaya pihak lawan "takut" akan pengenaan sanksi pidana, dan akhirnya tujuan untuk mendapatkan prestasi akan segera diperoleh.Terjadinya hal yang demikian itu menurut Yahman karena masyarakat tidak mengerti dan tidak memahami hukum, sehingga setiap permasalahan yang terjadi dilaporkan, apakah masalah yang dihadapi masuk kedalam lingkup hukum perdata atau hukum pidana, ia tetap melaporkan kepada pihak Polri dengan harapan cepat terselesaikan urusannya. $^{9}$

Salah satu contoh kasus hubungan privat diselesaikan melalui jalur hukum pidana dapat dilihat pada Putusan Mahkamah Agung RI No. 449K/Pid/2001, dimana dalam kasus tersebut, seorang pengusaha kayu menerima sejumlah uang pembelian kayu, namun tidak dapat memenuhi kewajibannya untuk mengirim kayu kepada pemesannya "Yayasan Baret Jingga" yang telah menyerahkan uang pesanannya sesuai isi kontrak. Kayu baru

${ }^{8}$ F.A.F Lamintang, Theo Lamintang, Pembahassan KUHAP menurut IImu Pengetahuan Hukum Pidana dan Jurisprudensi, Jakarta: Sinar Grafika, 2010, h. 51.

${ }^{9}$ Yahman, Op.Cit. h. 4-6 
Media Komunikasi dan Informasi Hukum dan Masyarakat

dikirim sebagian, tidak dapat memenuhi pesanan karena suatu hal. Pada putusan Tingkat Pertama dan Banding, pengadilan memutuskan bahwa perbuatan penipuan terbukti dilakukan, namun pada tingkat Kasasi, Mahkamah Agung membatalkan putusan pengadilan Tingkat Banding yang amar putusannya mengatakan : perbuatan terbukti, tetapi bukan merupakan tindak pidana. ${ }^{10}$ Kaidah hukum yang didapat berdasarkan kasus tersebut, bahwa perbuatan tersebut bukan merupakan eks-Pasal 378 KUHP, melainkan wanprestasi atau ingkar janji. ${ }^{11}$

Di lain kasus, hubungan kontraktual yang terbukti sebagai tindak pidana penipuan dapat dilihat dalam Putusan Mahkamah Agung RI No.2674 K/Pid/2006 tanggal 6 Maret 2008. Duduk perkaranya adalah seorang Terdakwa dengan nama Zulkifli Zainoel Arifin mengaku sebagai Direktur Utama PT Inoventura Angkasa bergerak dalam usaha di bidang pemasangan AC di Sekretariat Presiden Republik Indonesia, bekerja sama dengan saksi Firza Achmad Paloh. Dalam kerja sama dengan saksi,Terdakwa memerlukan modal Rp.150.000.000, Terdakwa akan memberikan keuntungan $8,75 \%$ dan akan dibuatkan draft perjanjian kerja sama, Terdakwa akan memberikan surat perintah kerja (SPK) dari Sekretariat Negara jika uang sudah diterima. Ketika Terdakwa telah menerima uang sebesar Rp 50.000.000 dari saksi Pietra Paloh, oleh Terdakwa dikatakan uang tersebut masih kurang, kemudian oleh saksi Firza Achmad Paloh menyerahkan uang yang kedua sebesar Rp 30.000.000 pada 2 bulan berikutnya.

\footnotetext{
${ }^{10} /$ bid, h. 249

${ }^{11}$ Ibid,
}

Namun setelah ditunggu sampai waktu yang disepakati, Terdakwa tidak kunjung memberikan keuntungan kepada saksi seperti apa yang diperjanjikan. Hingga pada saat saksi menelpon Terdakwa yang memerlukan uang untuk membeli cincin pertunangan, Terdakwa menyanggupi untuk membelikan cincin berlian seharga $\mathrm{Rp}$ 18.000.000, dua lembar cek masing-masing $\mathrm{Rp} \quad 5.000 .000$ dan $\mathrm{Rp}$ 8.000.000. dan cek yang kedua tidak dapat diuangkan karena resinya tidak ada dan dikembalikan kepada Terdakwa, cincin berlian dari Terdakwa tidak ada sertifikatnya ketika ditanya oleh toko berlian "Paris Jewellery" ternyata cincin tersebut hanya bernilai $\mathrm{Rp}$ 2.000.000.

Putusan Tingkat Pertama Pengadilan Negeri Jakarta Pusat tanggal 16 Mei 2005 Nomor : 1782/Pid.B/2004/PN.JKT PST menyatakan dalam amar putusannya bahwa Terdakwa Zulkifli Zainoel Arifin secara sah dan meyakinkan bersalah melakukan tindak pidana "penipuan sebagai perbuatan berlanjut". Pada Putusan Tingkat Banding dan Tingkat Kasasi, masing-masing putusan menguatkan Putusan Tingkat Pertama.

Kaidah hukum yang diambil dalam amar putusan Hakim dalam perkara tersebut adalah bahwa terdakwa terbukti melakukan tipu muslihat, rangkaian kata bohong sebelum menutup kontrak, kerja sama pemasangan AC tidak pernah terwujud. Unsur-unsur sengaja dalam delik penipuan telah terbukti.

Satu contoh kasus terbaru yang cukup menyita perhatian publik dan menuai pro dan kontra adalah kasus yang menjadi perhatian publik terkait masalah perjanjian yang dibawa ke jalur hukum pidana yaitu kasus First Travel. Ada argumentasi dari beberapa sarjana hukum bahwa kasus First Travel seharusnya 
Media Komunikasi dan Informasi Hukum dan Masyarakat

diselesaikan melalui jalur perdata dengan mengajukan gugatan perdata, namun sebagian lagi menganggap jalan yang penyelesaian yang ditempuh sudah benar.

Di Indonesia aturanmengenai hubungan perseorangan tentang perikatan diatur dalam buku III Kitab Undang Undang Hukum Perdata (selanjutnya disingkat KUHPerdata) tentang perikatan.Pasal 1233 KUHPerdata dinyatakan bahwa perikatan itu dapat lahir dari UndangUndang dan Perjanjian.

Berbicara mengenai perjanjian, KUHPerdata dalam Pasal 1313 memberikan definisi mengenai perjanjian yang mengatakan :Suatu perjanjian adalah suatu perbuatan dengan mana satu orang atau lebih mengikatkan dirinya terhadap satu orang lain atau lebih". Dalam melaksanakan suatu perjanjian, sering terjadi di antara para pihak yang telah melakukan perjanjian melakukan ingkar janji, tidak melaksanakan hak dan kewajiban yang telah disepakati antara kedua belah pihak,sehingga menimbulkan permasalahan hukum.

Dalam persepektif perlindungan hak asasi manusia (selanjutnya disebut HAM) dinyatakan bahwa kebebasan berkontrak merupakan HAM yang harus dihormati dan dilindungi. Pasal 11 International Convenant on Civil and Political Rights (ICCPR) lewat UndangUndang No. 12 tahun 2005 Tentang Pengesahan International Covenant on Civil and Political Rights (selanjutnya disebut UU pengesahan (CCPR), dinyatakan : "dan bahwa tidak seorang pun boleh dipenjarakan hanya atas dasar ketidakmampuannya memenuhi kewajiban kontraktualnya". Hal senada juga ditentukan di dalam Pasal 19 ayat (2) Undangundang Nomor 39 Tahun 1999 Tentang Hak Asasi Manusia (selanjutnya disebut UUHAM) yang mengatakan : "Tidak seorangpun atas putusan pengadilan boleh dipidana penjara atau kurungan berdasarkan atas alasan ketidakmampuan untuk memenuhi suatu kewajiban dalam perjanjian utang-piutang". Ketentuan norma dari kedua pasal tersebut dapat disimpulkan bahwa, seseorang tidak dapat dihukum penjara karena tidak dapat memenuhi kewajiban perjanjiannya.

masalah normatif di atas perlu dilakukan penelitian untuk menentukan parameter normatif antara perbuatan wanprestasi dan penipuan dalam hukum pidana. Alasan ini pula yang melatarbelakangi pentingnya penelitian ini dilakukan.

Harapan dilakukannya penelitian ini adalah agar dicapainya kepastian hukum mengenai parameter menentukan perbuatan wanprestasi dan penipuan, agar setiap hak sipil dapat dihormati dan dilindungi. Melalui karya ilmiah ini, diharapkandapat memberikan kontribusi bagi para praktisi hukum dalam mengambil keputusan terkait wanprestasi dan penipuan. Pada sisi lain agar dalam praktik penegakan hukum pidana dipergunakan pada pada tahap akhir atau ultimum remedium dan membuka peluang bagi penegak hukum untuk menyelesaikan perkara pidana yang berwatak perjanjian diselesaikan secara perdata melalui mediasi.

Hal inilah yang mendasari penulis bahwa perlu dilakukannya penelitian dalam hal menentukan antara perbuatan wanprestasi dan tindak pidana penipuan dari suatu perjanjian.

\section{B. Perumusan masalah}

Dari latar belakang di atas, dapat ditarik beberapa perumusan masalah yang antara lain:

1. Apa yang menjadi ciri-ciri normatif dari perbuatan Wanprestasi dan Tindak Pidana Penipuan? 
Media Komunikasi dan Informasi Hukum dan Masyarakat

2. Apa faktor penentu Wanprestasi dan beberapa konsep dasar dalam rangka Penipuan dari suatu perjanjian?

3. Bagaimana pertanggungjawaban perbuatan wanprestasi dan Tindak pidana Penipuan dari suatu perjanjian?

\section{Tujuan Penelitian}

Dari rumusan masalah di atas dapat dikemukakan tujuan penelitian ini adalah:

1. Mengetahui ciri-ciri normatif dari wanprestasi dan penipuan.

2. MenganalisisFaktor penentusuatu perjanjian sebagai perbuatan wanprestasi atau tindak pidana penipuan.

3. Menganalisis pertanggungjawaban wanprestasi dan tindak pidana penipuan dari suatu perjanjian.

\section{Manfaat Penelitian}

\section{a. Manfaat teoritis}

Secara teoritis, penelitian ini bermanfaat menambah pemahaman ilmu pengetahuan di bidang hukum, khususnya mengenai parameter penentu perbuatan wanprestasi dan tindak pidana penipuan dari suatu perjanjian.

\section{b. Manfaat praktis}

Secara praktis, penelitian ini bermanfaat sebagai bahan masukan bagi pihak pengambi keputusan / aparat penegak hukum penegak hukum. Khususnya yang berkaitan dengan penentu perbuatan wanprestasi dan penipuan

\section{E. Definisi Operasional}

Definisi Operasional didalam sebuah penelitian bertujuan untuk menghindari kesalahan pemahaman dalam menafsirkan istilah yang berkaitan dengan judul atau kajian penelitian. Untuk menjawab permasalahan dalam penelitian penelitian ini perlu didefinisikan menyamakan persepsi, yaitu sebagai berikut :

1. Perjanjian adalah kesepakatan antara satu pihak atau lebih untuk suatu objek atau kepentingan tertentu yang berorientasi pada materi atau dapat dinilai dengan uang.

2. Kontrak adalah perjanjian yang diakukan secara tertulis.

3. Wanprestasi adalah perbuatan ingkar janji yang merujuk pada perjanjian yang bisa dinilai dengan uang.

4. Penipuan adalah tindak pidana, yaitu rangkaian tipu muslihat sedemikian rupa yang dilakukan oleh seseorang untuk membujuk orang lain agar sepakat melakukan suatu hal sesuai dengan kehendak yang diinginkan dan memperoleh keuntungan dari perbuatan tersebut.

5. Parameter adalah tolak ukur atau ukuran, dalam penelitian penulisan penelitian iniadalah tolak ukur untuk menentukan wanprestasi dan penipuan.

\section{METODE PENELITIAN}

\section{A. Objek Penelitian}

Objek penelitian ini adalah norma hukum Pasal 1243 KUHPerdata tentang wanprestasi dan norma hukum Pasal 378 KUHP tentang tindak pidana penipuan.

\section{B. Sifat/Materi Penelitian}

Penelitian ini adalah penelitian normatif tentang kaedah hukum yang termuat pada Pasal 1243 KUHPerdata dan Pasal 378 KUHP. Sifat penelitian ini adalah penelitian deskriptif analisis yuridis. Dikatakan deskriptif karena dalam penelitian ini menggambarkan secara rinci dan utuh, sistematis dan menyeluruh tentang kaedah hukum yang termuat pada 
Media Komunikasi dan Informasi Hukum dan Masyarakat

Pasal 1243 KUHPerdata dan Pasal 378 KUHP.

Dikatakan analisis karena penelitian ini menguraikan secara lengkap, sistematis, menggunakan metode tertentu dan rinci tentang figur hukum dari norma hukum Pasal 1243 KUHPerdata dihubungkan dengan Pasal 378 KUHP. Dikatakan yuridis karena penelitian ini menggambarkan dan menganalisis penerapan norma hukum yang terkandung pada Pasal 1243 KUHPerdata dan Pasal 378 KUHP oleh pengadilan.

\section{Metode Pendekatan}

'Penelitian ini dilakukan melalui pendekatan yuridis normatif yaitu suatu penelitian yang secara deduktif menganalis norma hukum tertentu. Artinya analisis data dalam penelitian ini melalui pendekatan berdasarkan bahan hukum utama dengan cara menelaah teori-teori, konsep-konsep, asas-asas hukum serta peraturan perundang-undangan yang berhubungan dengan norma hukum Pasal 1243 KUHPerdata dan Pasal 378 KUHP.

\section{Data dan Teknik Pengumpulan Data}

1. Jenis data

Data yang dipergunakan dalam penelitian ini adalah data sekunder yang berupa literatur hukum, undang-undang, putusan pengadilan, makalah dan atau artikel yang termuat di media cetak maupun elektronik. Data sekunder yang dipergunakan dalam penelitian ini terdiri dari bahan hukum primer yang bersifat otoritatif yang artinya mempunyai otoritas, bahan hukum sekunder dan bahan hukum tertier.

Bahan hukum primer yang bersifat otoritatif yang dipergunakan dalam penelitian ini terdiri dari: a. Undang-Undang Dasar Republik Indonesia Tahun 1945.

b. Kitab Undang-undang Hukum Pidana.

c. Kitab Undang-undang Hukum Perdata

d. Putusan Mahkamah Agung Republik Indonesia.

Bahan hukum sekunder yang dipergunakan dalam penelitian ini adalah doktrin hukum yang termuat di dalam buku literatur hukum perdata dan pidana, artikel dalam jurnal hukum, atau makalah yang ditulis para ahli yang materinya relevan dengan penelitian ini. Sedangkan bahan hukum tertier yang dipergunakan dalam penelitian ini adalah kamus hukum, ensiklopedia hukum dan kamus bahasa Indonesia.

\section{Sumber data}

Data sekunder untuk penelitian ini diperoleh melalui kepustakaan atau studi kepustakaan meliputi Buku-buku hukum, Undang-undang, Putusan Pengadilan, dan lainlain baik yang termuat pada media cetak maupun media elektronik.

\section{E. Alat Pengumpulan Data}

Dalam upaya memperoleh data yang akurat, dalam penelitian ini data diperoleh dengan menggunakan alat pengumpulan data menelaah dan menginventarisasi bahan-bahan hukum di kepustakaan (Library Research). Yaitu pengumpulan data dengan mengadakan studi telaah terhadap buku, literatur, Undang-Undang yang mempunyai korelasi dengan masalah yang diteliti yaitu mengenai parameter penentu pebuatan Wanprestasi dan Tindak Pidana Penipuan dari Satu Perjanjian.

\section{F. Analisis Data}


Media Komunikasi dan Informasi Hukum dan Masyarakat

Analisis data dalam penelitian ini dilakukan analisis kualitatif.Data yang telah dihimpun dan diklasifikasi sesuai dengan permasalahan penelitian ini kemudian dilakukan analisis secara kualitatif (content analysis) dengan melakukan penafsiran atas data yang ada.

Penafsiran terhadap data yang dianalisis dapat menggunakan penafsiran otentik, gramatika maupun penafsiran teleologis khususnya terkait dengan sifat melawan hukum dari Pasal 1243 KUHPerdata dan Pasal 378 KUHP untuk dapat membedakan bentuk perbuatan wanpretasi dengan perbuatan pidana penipuan atas suatu perjanjian.

Hasil analisis kualitatif atau penafsirkan data kemudian diambil maknanya sehingga diketahui inti dari isi norma hukum yang diteliti dan dari makna tersebut digunakan untuk menjawab permasalahan yang ada sehingga diperoleh kesimpulan dari penelitian ini.

\section{PEMBAHASAN}

A. Ciri-Ciri Normatif dari Wanprestasi dan Penipuan

1. Ciri Normatif Wanprestasi

Manusia adalah makhluk yang paling sempurna di dunia ini. Kesempurnaan manusia dapat dipahami karena ia memiliki akal dan kehendak. Manusia dengan akalnya dapat melakukan penilaian, penjelasan dan pilihan.

Oleh karenanya manusia, secara kodrati, memiliki hak fundamental yaitu kebebasan, hak hidup, dan keamanan pribadi.Dalam realitas kehidupan manusia, hakfundamental itu saling berinteraksi antaramanusia yang satu dengan manusia lainnya;salah satunya dalam wujud kontrak. ${ }^{12}$

ChantalMak menerangkan kontrak mengandung hak fundamental manusia dapat dilihat daridua kriteria:

Pertama, dilihat dari sisi formal; Kedua, dari sisi substansi. Secara formal suatuhak fundamental adalah hak yang ditentukandalam ketentuan konstitusi, sedangkan secarasubstansi hak adalah norma yang bertujuanuntuk menjamin martabat manusia atau hak yang mendasar bagi perlindungan otonomi pribadi. Kebebasan berkontrak adalah hak dasar seorang individu untuk masuk ke dalamperjanjian Itu memperoleh atau menyerahkan harta, jasa atau mengubah hubungan hukum. ${ }^{13}$

Pengaturan kontrak sebagai hak fundamental manusia dari sisi substansial di Indonesia dapat dilihat pada Pasal 1338 KUHPerdata yang di dalamnya terkandung asas kebebasan berkontrak. Secara umum pengaturan kontrak atau perjanjian dapat ditemui dalam KUHPerdata pada Buku III titel 2.

Perkataan "kontrak" dan "perjanjian" itu

sama, dalam praktek-praktek sehari-hari mengartikan kontrak itu sebagai akta, tapi sebenarnya kontrak itu perjanjian. ${ }^{14}$ Dalam hukum Islam, merujuk pada istilah yang berkaitan dengan perjanjian, agama Islam memiliki beberapa istilah sebagaimana Mashudi mengatakan:

Dalam Al-Qur'an, setidaknya ada 2 (dua) istilah yang berkaitan dengan perjanjian, yaitu kata akad (al-'aqdu)

${ }^{12}$ Zulfirman, "Kontrak sebagai sarana mewujudkan Kesejahteraan Sosial", Jurnal Rechtsvinding, Vol. 6, № 3, (Desember 2017), h. 405

${ }_{13}$ Zulfirman, Hak Dasar Manusia Dalam Kontrak dan Perlindungannya di Indonesia, Intelegensia, Malang, 2017, h.274

${ }^{14}$ H.Mashdui, et.al, Pengertian-Pengertian Elementer Hukum Perjanjian Perdata. CV. Mandar Maju, Bandung, 2001. h. 11 
Media Komunikasi dan Informasi Hukum dan Masyarakat

dan kata 'ahd (al-ahdu). Kata yang disebut pertama, secara etimologis berarti perjanjian, perikatan dan pemufakatan (al-ittifaq). Al-Qur'an memakai kata ini dalam arti perikatan dan perjanjian. Hal ini dapat dilihat dalam QS.Al-Maidah ayat (1). Sedangkan kata al-'Ahdu, secara etimologis berarti masa, pesan, penyempurnaan, dan janji atau perjanjian, hal ini dapat dilihat dalam AlQur'an surat An-Nahl ayat (91) dan AlIsra ayat (34). ${ }^{15}$

Kontrak/perjanjian sah apabila memenuhi syarat-syarat sahnya kontrak. syarat sah kontrak/perjanjian diatur dalam Pasal 1320 KUHPerdata, yaitu adanya kata sepakat mereka yang membuatnya, kecakapan untuk membuat suatu perikatan, suatu hal tertentu dan suatu sebab yang halal. Pengertian kata sepakat mereka yang mengikatkan dirinya yang dimaksud adalah izin kedua belah pihak berdasarkan persetujuan kehendak mereka masing-masing, artinya pada waktu kontrak itu diadakan tidak terdapat paksaan, penipuan, atau kekeliruan ${ }^{16}$.

Kontrak/perjanjian yang telah disepakati mengandung asas pacta sunt servanda. Asas ini mempunyai arti bahwa setiap kontrak yang telah dibuat secara sah, harus ditepati dan mengikat kedua belah pihak. Asas pacta sunt servanda layaknya sebuah undang-undang yang harus dipatuhi sebagaimana Pasal 1338 ayat (1) BW, yang menyatakan : "kontrak/perjanjian yang dibuat secara sah berlaku sebagai undang-undang." Janji harus ditepati, menepati janji merupakan kodrat manusia. ${ }^{17}$

Suatu perjanjiantidak lepas dari masalah Iktikad baik dalam melaksanakan

\footnotetext{
${ }^{15}$ Taryana. Op.Cit, h. 247

${ }^{16}$ Yahman., Op.Cit. h. 72

${ }^{17}$ Ibid, h. 76
}

perjanjian maupun saat membuat perjanjian. Iktikad baik merupakan unsur subjektif dari syarat sah suatu perjanjian. Iktikad baik atau te goeder trouw (Belanda) atau in good faith (Inggris) sangat erat kaitannya dengan kepatutan atau keadilan dan ukuran itikad baik ini harus ada pada para pihak, baik itu kreditur maupun debitur ${ }^{18}$.

Iktikad baik dalam kontrak merupakan lembaga hukum (rechtsfiguur) yang berasal dari hukum Romawi yang kemudian diserap oleh civil law. Di beberapa negara yang menganut sistem hukum common law, seperti Amerika Serikat, Australia, Selandia Baru dan Kanada. ${ }^{19}$ Khairandy mengatakan :

Walaupun iktikad baik menjadi asas
penting dalam hukum kontrak di
berbagai sistem hukum di atas, tetapi
asas iktikad baik tersebut masih
menimbulkan sejumlah permasalahan.
Permasalahan tersebut di antaranya
berkaitan dengan keabstrakan makna
iktikad baik, sehingga timbul pengertian
iktikad baik dari perspektif waktu,
tempat, dan orangnya. Selain tidak ada
makna tunggal iktikad baik, dalam
praktek timbul pula permasalahan
mengenai tolok ukur, dan fungsi iktikad
baik tersebut. akibatnya, makna dan
tolok ukur serta fungsi iktikad baik lebih
banyak disandarkan pada sikap atau
pandangan hakim yang ditentukan
secara kasus per kasus ${ }^{20}$. Mengingat iktikad baik dalam kontrak merupakan doktrin atau asas yang berasal dari hukum Romawi, maka untuk mendapatkan pemahaman yang lebih baik harus dilacak ke dalam doktrin iktikad baik yang berkembang dalam hukum Romawi tersebut.

${ }^{18}$ Hardijan Rusli. Hukum Perjanjian Indonesia dan Common Law. Pustaka Sinar Harapan, Jakarta, 1993 h. 119

${ }^{19}$ Ridwan Khairandy, Iktikad Baik dalam Kebebasan Berkontrak, Universitas Indonesia, Fakultas Hukum, Pascasarjana, Jakarta, 2003, h. 128 ${ }^{20}$ Ibid, h. 129 
Media Komunikasi dan Informasi Hukum dan Masyarakat

Iktikad baik dalam hukum kontrak Romawi mengacu kepada tiga bentuk perilaku para pihak dalam kontrak.

Pertama, para pihak harus memegang teguh janji atau perkataannya. Kedua, para pihak tidak boleh mengambil keuntungan dengan tindakan yang menyesatkan terhadap salah satu pihak, Ketiga, para pihak mematuhi kewajibannya dan berperilaku sebagai orang terhormat dan jujur, walaupun kewajiban tersebut tidak secara tegas diperjanjikan. ${ }^{21}$

Di Indonesia, keharusan pelaksanaan iktikad baik dalam membuat suatu perjanjian tercantum dalam Pasal 1338 ayat (3) KUHPerdata yang menyatakan bahwa suatu perjanjian harus dilaksanakan dengan iktikad baik. Pasal ini menimbulkan pertanyaan apakah tidak diperlukan iktikad baik untuk membuat perjanjian (pra kontrak/perjanjian)?

\section{J.M.Van Dunne membagi tahapan} kontrak dalam tiga fase, yakni fase pra kontrak (precontractuale fase), fase pelaksanaan kontrak (contractuale fase) dan fase pasca kontrak (postcontractuale fase). Iktikad baik sudah harus ada sejak fase pra kontrak dimana para pihak mulai melakukan negosiasi hingga mencapai kesepakatan, dan fase pelaksanaan kontrak. ${ }^{22}$

Khairandy berpendapat bahwa ruang lingkup pengaturan iktikad baik dalam berbagai sistem hukum umumnya hanya mencakup iktikad baik dalam fase pelaksanaan kontrak, belum mencakup fase pra kontrak ${ }^{23}$. Mengacu pada pendapat Agung Sujatmiko mengutip Yohanes Sogar Simamora yang menerangkan kriteria perilaku iktikad baik dalam pelaksanaan perjanjian pengujiannya didasarkan pada norma-norma objektif yang tidak

\footnotetext{
${ }^{21}$ Ibid, h. 132

${ }^{22}$ Ibid, h 190

${ }^{23}$ Ridwan Khairandy, Ibid, h 191
}

tertulis ${ }^{24}$.Zulfirman berpendapat iktikad baik berlaku pada fase pra kontrak, sebagaimana dikatakannya:

Paksaan, tipuan, dan kekeliruan adalah
parameter normatif terkait iktikad baik
seseorang yang akan membangun
perjanjian; kesemuanya berkaitan
dengan ketidakpatutan, ketidakjujuran
dan ketidakadilan dalam membuat
perjanjian. Paksaan, tipuan dan
kekeliruan diambil alih dari norma-
norma objektif yang tidak tertulis yang
berkembang di dalam masyarakat
diformalkan menjadi norma hukum
tertulis. Itulah sebabnya mengapa Pasal
1338 KUHPerdata tidak lagi ditentukan
iktikad baik sebagai dasar membuat
perjanjian.25

Selain iktikad baik dalam perjanjian juga berlaku prinsip mengikatnya suatu perjanjian yang telah dibuat secara sah oleh masingmasing pihak. Perjanjian yang sudah dibuat tidak dapat ditarik secara sepihak kecuali atas kesepakatan kedua belah pihak. Hal ini tercantum dalam Pasal 1338 ayat (2) KUHPerdata yang merupakan kelanjutan dari Pasa 1338 ayat (1) KUHPerdata.

Suatu perjanjian akan melahirkan kewajiban yang bersifat positif dan negatif. Kewajiban yang bersifat positif (positive duties) pada dasarnya merupakan kewajiban untuk melakukan sesuatu (duty to do), sedangkan yang bersifat negatif (negative duties) merupakan suatu kewajiban untuk mematuhi larangan (duty not to do) ${ }^{26}$. Kewajiban yang lahir dari suatu perjanjian disebut prestasi. Jadi, prestasi adalah suatu yang wajib harus dipenuhi oleh debitor dalam setiap perikatan. ${ }^{27}$

\footnotetext{
${ }^{24}$ Moch. Isnaeni, Perkembangan Hukum Perdata di Indonesia, Laksbang Grafika, Yogyakarta, 2013. h 189

${ }^{25}$ Zulfirman, Hak Dasar Manusia Dalam Kontrak dan Perlindungannya di Indonesia, Intelegensi Media, Malang, 2017. h. 235

${ }^{26} /$ bid, h. 79

${ }^{27}$ Riduan Syahrani, Seluk Beluk dan Asas-Asas Hukum Perdata, Bandung, 1992, h. 228
} 
Media Komunikasi dan Informasi Hukum dan Masyarakat

Prinsip yang terkandung dalam hubungan kontraktual yaitu adanya jaminan kepastian pelaksanaan kontrak. Apabila tidak adanya suatu keseimbangan pelaksanaan hak dan kewajiban dalam hubungan kontraktual, maka akan timbul pelanggaran kepentingan atau hak salah satu pihak, jika hal ini terjadi maka timbul suatu peristiwa hukum yang dinamakan "wanprestasi". ${ }^{28}$

Wanprestasi harus didasari adanya suatu perjanjian, baik perjanjian tersebut dibuat secara lisan maupun tertulis, baik dalam bentuk perjanjian dibawah tangan maupun dalam akta autentik. Seseorang tidak dapat dinyatakan wanprestasi, jika ia tidak terikat dalam suatu hubungan kontraktual29.

Ciri normatif wanprestasi dapat ditemukan dalam Pasal 1243 KUHPerdata yang menyatakan bahwa :

"Penggantian biaya, rugi, dan bunga karena tidak dipenuhinya suatu perikatan, barulah mulai diwajibkan apabila si berutang setelah dinyatakan lalai memenuhi perikatannya, tetap melalaikannya, atau jika sesuatu yang harus diberikan atau dibuatnya, hanya dapat diberikan atau dibuat dalam tenggang waktu yang telah dilampauinya."

Yahman mengutip pendapat Setiawan, dalam praktik sering dijumpai ingkar janji dalam hukum perdata, ada tiga bentuk ingkar janji :

a. Tidak memenuhi prestasi sama sekali

b. Terlambat memenuhi prestasi

baik ${ }^{30}$

c. Memenuhi prestasi secara tidak

Sedangkan menurut Subekti, wanprestasi seorang debitur dapat berupa empat jenis yaitu :

a. Tidak melakukan apa yang disanggupi akan dilakukannya

b. Melaksanakan apa yang dijanjikannya, tetapi tidak sebagaimana yang dijanjikan. c. Melakukan apa yang dijanjikan tetapi terlambat.d. melakukan

${ }^{28}$ Yahman, Loc.Cit

${ }^{29}$ Ibid, h. 24

${ }^{30}$ Ibid, h. 82 sesuatu yang menurut perjanjian tidak boleh dilakukannya. ${ }^{31}$

M.Yahya Harahap mengatakan, secara umum wanprestasi yaitu "pelaksanaan kewajiban yang tidak tepat pada waktunya atau dilakukan tidak menurut selayaknya"32.

Dalam praktik di masyarakat, untuk menentukan sejak kapan seseorang dikatakan wanprestasi tidaklah selalu mudah.

Riduan Syahraniberpendapat cukup mudah menentukan wanprestasi untuk "tidak berbuat sesuatu", namun lain halnya dalam perjanjian yang prestasinya untuk "memberi sesuatu" atau untuk "berbuat sesuatu" yang tidak menetapkan kapan debitor harus memenuhi prestasi itu, maka untuk pemenuhan prestasi tersebut debitor harus lebih dahulu diberi tegoran (sommatie/ingebrekestelling) agar ia memenuhi kewajibannya. ${ }^{33}$

Tentang bagaimana caranya memberikan tegoran (sommatie/ingebrekestelling) terhadap debitor agar jika ia tidak memenuhi tegoran itu dapat dikatakan wanprestasi, diatur dalam Pasal 1238 BW yang menentukan, bahwa tegoran itu harus dengan "surat perintah" atau dengan "akta sejenis"34.

Yang dimaksud dengan "surat perintah" dalam Pasal 1238 BW tersebut adalah peringatan resmi oleh jurusita pengadilan. Sedangkan yang dimaksud dengan "akta sejenis" adalah suatu tulisan biasa (bukan resmi), surat maupun telegram yang tujuannya sama yakni untuk memberi peringatan kepada debitor agar memenuhi prestasi dalam seketika atau dalam tempo tertentu (arrest Hoge Raad tanggal 9 Desember 1892) ${ }^{35}$.

\footnotetext{
${ }^{31}$ Subekti II, Op.Cit. h. 45

${ }^{32}$ M. Yahya Harahap, Op.Cit, h. 60

${ }^{90}$ Riduan Syahrani, Op.Cit, 228

${ }^{34}$ lbid, h. 229

${ }^{35}$ Ibid
} 
Media Komunikasi dan Informasi Hukum dan Masyarakat

Dari uraian di atas, maka dapat ditarik kesimpulan bahwa ciri normatif wanprestasiialah :

1. Subjek norma dalam wanprastasi adalah individu dengan individu.

2. Wanprestasi timbul sebagai akibat suatu perjanjian yang dibuat oleh subjek hukum dalam lapangan hukum privat.

3. Wanprestasi identik dengan tidak terpenuhinya prestasi dengan baik oleh salah satu subjek hukum.

4. Tidak terpenuhinnya prestasi terdiri dari:

a. Tidak memenuhi prestasi sama sekali

b. Terlambat memenuhi prestasi

c. Melaksanakan lain daripada apa yang diperjanjikan

d. Melakukan apa yang menurut perjanjian tidak boleh dilakukan

5. Wanprestasi senantiasa diawali dengan pemberian tegoran atau somasi.

\section{Ciri Normatif Penipuan}

$\mathrm{Di}$ atas telah di bahas bahwa manusia dalam menjalankan interaksi dengan manusia lainnya tidak selamanya dapat berjalan lancar. Adakalanya ikatan yang dicapai dalam suatu hubungan interaksi tidak dipenuhi oleh salah satu pihak. Salah satu sebab tidak tercapainya ikatan yang telah disepakati adalah karena penipuan. Konsep penipuan dalam KUHPerdata dapat dijumpai dalam Pasal 1328, yaitu :" Penipuan merupakan suatu alasan untuk pembatalan perjanjian, apabila tipu muslihat, yang dipakai oleh satu pihak, adalah sedemikian rupa hinga terang dan nyata bahwa pihak yang lain tidak telah membuat perikatan itu jika tidak dilakukan tipu muslihat tersebut. Penipuan tidak dipersangkakan, tetapi harus dibuktikan. "

Lembaga hukum Pasal 1328 KUHPerdata tentang penipuan dalam hukum perdata, sama dengan Pasal
378 KUHP tentang penipuan dalam hukum pidana. Konsep penipuan yang terdapat dalam Pasal 1328 KUHPerdata yaitu, adanya cacat kehendak. Cacat kehendak diakibatkan karena adanya suatu :kekhilafan atau lalai, paksaan dan penipuan. Kemudian konsep penipuan dalam Pasal $378 \mathrm{KUHP}$, yaitu adanya rangkaian kata bohong, tipu muslihat, keadaan palsu, martabat palsu. Kedua koridor hukum ini dapat ditempuh atau dijadikan dasar seseorang yang dirugikan oleh salah satu pihak dalam menutup kontrak atau perjanjian melakukan tuntutan pidana atau gugatan ganti kerugian ${ }^{36}$.

Penipuan dalam hukum pidana merupakan pekerjaan. Artinya penipu itu pekerjaannya. ${ }^{37}$

Kejahatan penipuan (bedrog) dimuat dalam Bab XXV Buku II KUHP, dari Pasal 378 s/d Pasal 395. Title asli bab ini adalah bedrogyang oleh banyak ahli diterjemahkan sebagai penipuan, atau ada juga yang menerjemahkannya sebagai perbuatan curang. $^{38}$ Perkataan penipuan itu sendiri mempunyai dua pengertian, yakni :

a. Penipuan dalam arti luas, yaitu semua kejahatan yang dirumuskan dalam Bab XXV KUHP.

b. Penipuan dalam arti sempit, ialah bentuk penipuan yang dirumuskan dalam Pasal 378 (bentuk pokoknya) dan 379 (bentuk khususnya), atau yang biasa disebut dengan oplichting ${ }^{39}$.

Adapun seluruh ketentuan tindak pidana dalam Bab XXV ini disebut dengan penipuan, oleh karena dalam semua tindak pidana di sini

${ }^{36}$ Yahman, Op,Cit, h. 257

${ }^{37}$ R. Susilo, Kitab Undang-Undang Hukum Pidana Serta Komentar-komentar Pasal demi Pasal, Politea, Bogor, 1976, h. 225.

${ }^{38}$ Adami Chazawi. Kejahatan terhadap harta

benda. Media nusantara creative, Malang. 2004. h. 115 ${ }^{39} /$ bid 
Media Komunikasi dan Informasi Hukum dan Masyarakat

terdapatnya perbuatan-perbuatan yang bersifat menipu atau membohongi orang lain 40 .

Terjadinya penipuan dalam hukum pidana merupakan suatu hubungan hukum yang senantiasa diawali atau didahului hubungan kontraktual (characteristics of fraud has always started with a contractual relationship) ${ }^{41}$.

Yahman berpendapat, suatu hubungan hukum yang diawali dengan kontraktual tidak selalu merupakan perbuatan wanprestasi, akan tetapi dapat pula merupakan suatu perbuatan tindak pidana eks-Pasal 378 KUHP manakala suatu kontrak yang ditutup sebelumnya terdapat adanya tipu muslihat, keadaan palsu dan rangkaian kata bohong dari pelaku yang dapat menimbulkan kerugian pada orang lain atau korban, hal ini merupakan penipuan. ${ }^{42}$

Pasal 378 KUHP, menyatakan : "Barang siapa dengan maksud hendak menguntungkan diri sendiri atau orang lain dengan melawan hak, baik dengan memakai nama palsu maupun keadaan palsu, baik dengan akal dan tipu muslihat, maupun dengan karangan perkataan bohong, membuat utang atau menghapuskan piutang, dihukum penjara karena penipuan, dengan hukuman penjara selama-lamanya empat tahun"

Isi Pasal tersebut mempunyai unsur yang bersifat Subjektif dan Objektif. Unsur objektif dari Pasal 378 KUHP meliputi :

a. Perbuatan menggerakkan (Bewegen)

Kata menggerakan dalam Pasal 378 KUHP berasal dari terjemahan kata bewegen, selain diterjemahkan dengan kata menggerakkan, ada juga sebagian ahli dengan menggunakan istilah membujuk atau menggerakkan hati. KUHP sendiri tidak memberikan keterangan apapun tentang istilah bewegen itu. Susilo mengatakan menggerakkan atau membujuk adalah melakukan pengaruh dengan kelicikan terhadap orang, sehingga orang itu menurutinya berbuat sesuatu yang apabila mengetahui duduk perkara yang sebenarnya, ia tidak akan berbuat sedemikian itu. ${ }^{43}$ Menurut Chazawi menggerakkan dapat didefinisikan sebagai perbuatan mempengaruhi atau menanamkan pengaruh kepada orang lain. Objek yang dipengaruhi adalah kehendak seseorang. ${ }^{44}$ Chazawi lebih lanjut mengatakan,penipuan dilakukan dengan cara menggerakkan yang di dalamnya mengandung ketidakbenaran, palsu, dan bersifat membohongi atau menipu ${ }^{45}$.

Mengapa menggerakkan pada penipuan harus cara-cara yang palsu? Karena kalau menggerakkan dilakukan dengan cara yang sesungguhnya, cara yang benar dan tidak palsu, maka tidak mungkin kehendak orang lain (korban) akan menjadi terpengaruh, yang pada ahirnya ia menyerahkan benda, memberi hutang maupun menghapuskan piutang. ${ }^{46} \mathrm{Di}$ sinilah letak adanya mens rea (niat jahat) dari pelaku penipuan.

b. Yang Digerakkan adalah Orang

Pada umumnya orang yang menyerahkan benda, orang yang memberi hutang dan orang yang menghapuskan piutang sebagai korban penipuan adalah orang yang digerakkan itu sendiri. Tetapi hal itu bukan keharusan, karena dalam rumusan Pasal 378 tidak sedikitpun menunjukkan bahwa orang yang menyerahkan benda, memberi hutang ataupun menghapuskan piutang adalah orang yang digerakkan.

Orang yang menyerahkan benda, memberi hutang maupun menghapuskan

\footnotetext{
${ }^{43}$ R.Susilo, Op.Cit, hlm. 225

${ }^{44}$ Adami Chazawi, Op.Cit, h. 117

${ }^{45}$ Ibid,

${ }^{46}$ Ibid
} 
Media Komunikasi dan Informasi Hukum dan Masyarakat

piutang bisa juga oleh selain yang digerakkan, asalkan orang lain (pihak ketiga) menyerahkan benda itu atas perintah/kehendak orang yang digerakkan. Artinya penyerahan benda itu dapat dilakukan dengan perantaraan orang lain selain orang yang digerakkan ${ }^{47}$.

c. Tujuan Perbuatan

1. Menyerahkan Benda

Pengertian benda dalam penipuan mempunyai arti yang sama dengan benda dalam pencurian dan penggelapan, yakni sebagai benda berwujud dan bergerak. Adami mengatakan bahwa penipuan terjadi bukan oleh sebab telah terjadinya perbuatan menggerakkan, melainkan pada telah terjadi perbuatan menyerahkan benda oleh orang lain. ${ }^{48}$

Menyerahkan benda baru dianggap terjadi /selesai apabila dari perbuatan itu, telah sepenuhnya berpindah kekuasaan orang yang menerima. Dalam hal ini berarti telah putusnya hubungan kekuasaan (menguasai) antara orang yang menyerahkan dengan benda yang diserahkan.

2. Memberi hutang dan menghapuskan piutang Perkataan hutang disini tidak sama artinya dengan hitang piutang, melainkan diartikan sebagai suatu perjanjian atau perikatan ${ }^{49}$. Hoge Raad dalam suatu arrestnya (30-1-1928) menyatakan bahwa "yang dimaksud dengan hutang adalah suatu perikatan, misalnya menyetor sejumlah uang jaminan".

Oleh karena itulah memberi hutang tidak dapat diartikan sebagai memberi pinjaman uang belaka, melainkan diberi pengertian yang lebih luas sebagai membuat suatu perikatan hukum yang membawa akibat timbulnya kewajiban bagi orang lain untuk menyerahkan/membayar sejumlah

uang tertentu.

Perihal membuat hutang atau

menghapuskan piutang Chazawi menerangkan :

Dalam membuat hutang atau menghapuskan piutang, tidak dipersoalkan, apakah perjanjian seperti itu sah ataukah tidak menurut hukum, walaupun dari sudut hukum perjanjian dengan causa yang seperti itu adalah batal demi hukum. Hoge Raad dalam suatu arrestnya (14-1-1918) menyatakan bahwa "tidak menjadi persoalan apakah hutang yang dibuat itu mempunyai sebab/causa yang sah". Maksudnya arrest itu ialah bahwa untuk menerapkan penipuan tidak perlu dipersoalkan, artinya tidak perlu dibuktikan dalam persidangan tentang sah atau tidaknya perjanjian yang telah dibuat itu ${ }^{50}$.

Arrest itu sungguh tepat, karena apabila sudah terbukti dakwaan penipuan terdakwa dipidana dengan putusan berkekuatan hukum tetap, maka perjanjian itu batal demi hukum ${ }^{51}$.

4.Upaya-Upaya Penipuan

Ada beberapa hal untuk dapat melihat upaya-upaya penipuan sebagaimana yang dimaksudkan unsur Pasal 378 KUHP yaitu:

a. Dengan menggunakan nama palsu (valsche naam)

Pengertian nama palsu dikenal dua pengertian nama palsu. Pertama, diartikan sebagai suatu nama bukan namanya sendiri melainkan nama orang lain. Misalnya Abdruchim menggunakan nama temannya yang bernama Abdullah. Kedua, suatu nama yang tidak diketahui secara pasti nama pemilknya. Misalnya orang yang bernama Gino menggunakan nama Kempul. Nama Kempul tidak ada pemiliknya atau tidak diketahui secara
${ }^{47} /$ bid, h. 120

${ }^{48}$ /bid, h. 122

${ }^{49}$ Ibid, h. 123
${ }^{50} /$ bid., h. 124
${ }^{51} /$ bid 
Media Komunikasi dan Informasi Hukum dan Masyarakat

pasti ada tidaknya orang yang menggunakannya. 52

Timbul pertanyaan, bagaimana jika seseorang menggunakan nama orang lain yang sama dengan namanya sendiri, tetapi orang yang dimaksud itu berbeda. Misalnya seorang penjaga malam bernama Markaban memperkenalkan diri sebagai seorang dosen bernama Markaban, Markaban yang terakhir benar-benar ada dan diketahuinya sebagai dosen. Adami53 berpendapat bahwa disini tidak terjadi penggunaan nama palsu, akan tetapi menggunakan martabat/kedudukan palsu.

b. Menggunakan martabat/kedudukan palsu (valsche hoedanigheid)

Ada beberapa istilah yang sering digunakan sebagai terjemahan dari perkataan valsche hoedanigheid itu, ialah : keadaan palsu, martabat palsu, sifat palsu, dan kedudukan palsu.

Kedudukan palsu adalah suatu kedudukan yang disebut/digunakan seseorang , kedudukan mana menciptakan /mempunyai hak-hak tertentu, padahal sesungguhnya ia tidak mempunyai hak-hak tertentu itu. Jadi kedudukan ini jauh lebih luas pengertiannya daripada sekedar mengaku mempunyai suatu jabatan tertentu, seperti dosen, jaksa, kepala, notaris, dan lain sebagainya. Sudah cukup ada kedudukan palsu misalnya seseorang mengaku seorang pewaris , yang dengan demikian menerima bagian tertentu dari boedel waris, atau sebagai seorang wali, ayah atau ibu, kuasa, dan lain sebagainya. ${ }^{54}$

Hoge Raad dalam suatu arrestnya (273-1983) menyatakan bahwa "perbuatan menggunakan kedudukan palsu adalah bersikap secara menipu terhadap orang ketiga, misalnya sebagai seorang kuasa, seorang agen, seorang wali, seorang kurator ataupun yang dimaksud untuk memperoleh kepercayaan sebagai seorang pedagang atau seorang pejabat".

c. Menggunakan tipu muslihat (listige kunstgrepen) dan rangkaian kebohongan (zamenweefsel van verdichtsels).

Kedua cara menggerakkan orang lain ini sama-sama bersifat menipu atau isinya tidak benar atau palsu, namun dapat menimbulkan kepercayaan/kesan bagi orang lain bahwa semua itu seolah-olah benar adanya. Namun ada perbedaan, yaitu : pada tipu muslihat berupa perbuatan, sedangkan pada rangkaian kebohongan berupa ucapan/perkataan. ${ }^{55}$

B.Unsur Subjektif :

Usur subjektif dari suatu tindak pidana adalah unsur yang berhubungan dengan si pelaku perbuatan pidana. Dalam tindak pidana penipuan sebagaimana yang dimaksudkan dalam Pasal 378 KUHP unsur subjektifnya adalah :

1. Maksud untuk menguntungkan Diri Sendiri atau orang lain

2. Dengan melawan hukum

Unsur subjektif tentang maksud untuk menguntungkan diri sendiri atau orang lain. Maksud si pelaku dalam melakukan perbuatan menggerakkan harus ditujukan pada menguntungkan diri sendiri, juga ditujukan pada unsur lain di belakangnya, seperti unsur melawan hukum, menggerakkan, menggunakan nama palsu dan sebagainya. Kesengajaan dalam maksud ini harus sudah ada dalam diri si petindak, sebelum atau setidak-tidaknya pada saat memulai perbuatan menggerakkan. ${ }^{56}$

Unsur maksud sebagaimana yang diterangkan di atas, juga ditujukan pada unsur melawan hukum. Unsur maksud dalam rumusan penipuan ditempatkan sebelum unsur melawan

\footnotetext{
${ }^{52}$ /bid, h. 125

${ }^{53}$ Ibid,

${ }^{54}$ Ibid, h. 126
} 
Media Komunikasi dan Informasi Hukum dan Masyarakat

hukum, yang artinya unsur maksud itu juga harus ditujukan pada unsur melawan hukum. Oleh karena itu, melawan hukum disini adalah berupa unsur subjektif ${ }^{57}$.

Dalam hal ini sebelum melakukan atau setidak-tidaknya ketika memulai perbuatan menggerakkan,petindak telah memiliki kesadaran dalam dirinya bahwa menguntungkan diri sendiri atau orang lain dengan melakukan perbuatan menggerakkan, petindak telah memiliki kesadaran dalam dirinya bahwa menguntungkan diri sendiri atau orang lain dengan melakukan perbuatan itu adalah melawan hukum ${ }^{58}$.

Perlu diperhatikan ketentuan Pasal 378 KUHP sebagai tindak pidana penipuan masuk golongan tindak pidana terhadap kekayaan orang, maka steiap penipuan harus dianggap merugikan kekayaan orang lain, dan lagi menguntungkan diri dengan melanggar hukum sekiranya selau merugikan orang. 59

Dari uraian di atas,maka dapat diambil kesimpulan bahwa ciri normatif penipuan antara lain :

1. Subjek norma dalam penipuan adalah individu berhadapan dengan negara.

2. Penipuan terjadi akibat melawan hukum

3. Pelaku penipuan memiliki kesadaran untuk menguntungkan diri sendiri atau orang lain.

4. Cara melawan hukum yang dimaksud antara lain :

a. Memakai nama palsu atau martabat palsu

b. Memakai tipu muslihat atau rangkaian kebohongan

c. Menggerakkan orang lain untuk menyerahkan sesuatu kepadanya atau

\footnotetext{
${ }^{57}$ Ibid, h. 130

${ }^{58}$ Ibid.

59 Wiryono Prodjodikoro, Tindak Pidana Tertentu di Indonesia, Eresco Djakarta-Bandung, 1967, h. 37.
} supaya memberi utang maupun menghapus piutang.

5. Penipuan adalah kejahatan terahadap harta.

\section{B. Faktor Penentu suatu Perjanjian sebagai Perbuatan Wanprestasi atau Tindak Pidana Penipuan.}

Pada pembahasan di atas telah disinggung bahwa perjanjian merupakan bagian dari lapangan hukum privat, karena ikatan yang lahir dari perjanjian hanya berlaku mengikat bagi masing-masing pihak yang mengikatkan diri dalam perjanjian tersebut.

Namun pada praktiknya, ketika muncul masalah yang timbul dari perjanjian, tidak jarang dalam penyelesaiannya perjanjian yang pada dasarnya merupakan lingkup hukum privat (hukum perdata), dibawa ke ranah pidana dengan menggunakan Pasal 338 KUHP tentang penipuan sebagai penyelesaian dari masalah yang muncul dari perjanjian tersebut.

Dalam praktik penegakan hukum berkenaan dengan kontrak, untuk segera mendapatkan haknya seseorang kerap mencari jalan pintas, salah satunya dengan cara melaporkan kepada pihak kepolisian (Perkara Pidana). Argumentasi sederhana yang dikemukakan, yaitu supaya pihak lawan "takut" akan pengenaan sanksi pidana, dan akhirnya tujuan untuk mendapatkan prestasi akan segera diperoleh.

Implementasi kepastian hukum yang tidak tercermin dengan baik dalam praktik yang berkaitan dengan masalah perjanjian, maka perlu kiranya diteliti parameter penentu perbuatan wanprestasi dan penipuan agar tercapai kepastian hukum bagi masing-masing pihak yang melakukan perjanjian.

Berdasarkan uraian ciri normatif wanprestasi dan penipuan yang telah analisis 
Media Komunikasi dan Informasi Hukum dan Masyarakat

pada sub bab di atas, maka dapat dicermati antara wanprestasi dan penipuan mempunyai ciri normayang berbeda satu sama lainya, dari perbedaan ciri normatif tersebut dapat dianalisis parameter untuk menentukan bedawanprestasi dengan penipuan.

Dengan berpegang pada hasil analisis pada sub-bab di atas dan masing-masing sub bab tersebut dikomparasikan, maka dapat dikemukakan parameter penentu antara wanprestasi dan penipuan dapat adalah sebagai berikut :

1. Wanprestasi berhubungan erat dengan perjanjian sebagai hubungan hukum antar individu. Perjanjian itu sendiri dilahir atas kesepakatan sebagai mana dimaksud pada Pasal 1320 KUHPerdatayang mengandung pengertian para pihak saling menyatakan kehendak masing-masing untuk membuat suatu kehendak ; pernyataan satu pihak sudah disetujui oleh pihak lain ${ }^{60}$. Tegasnya perbuatan wanprestasi adalah pelanggaran atas hukum yang mereka lahirkan sendiri. Di sini isi subjek normanya indibidu dengan individu. Sedangkan penipuan adalah ketentuan undang-undang yang mengatur tentang kejahatan terhadap harta. Jadi parameter menentukan wanprestasi adalah pelanggaran terhadap janji atau hukum yang dibuat oleh para pihak dalam hubungan individu. Di sini subjek normanya negara berhadapan dengan individu.

Parameter menentukan suatu tindak pidana penipuan adalah perbuatan kejahatan (mens rea) terhadap harta kekayaan seseorang, yang dilakukan dengan cara culas atau melalui kebohongan sehingga seseorang menyerahkan barang atau benda

${ }^{60}$ Yahman., Op.Cit, h. 56 tidak atas dasar kesukarelaan. Pidana penipuan yang diatur di dalam KUHP karakter hukumnya berbeda dengan penipuan sebagai syarat sahnya perjanjian. Penipuan di sini ditujukan kepada kesepakatan sebagai syarat sahnya perjanjian bukan ditujukan kepada harta kekayaan sebagaimana ditentukan dalam penipuan dalam KUHP. Jelasnya, penipuan terkait dengan syarat sahnya perjanjian, kesepakatan yang ditutup dalam suatu perjanjian memberi cacat pada kehendak, sebab salah satu pihak memberikan kesesatan terhadap pihak lain dalam memberikan gambaran perjanjian. sehingga dalam penipuan kedudukan antara pihak satu dengan yang lainnya tidak seimbang.

2. Wanprestasi merupakan tindakan melanggar kewajiban pribadi yang muncul dari hubungan hukum yang dibuat oleh para pihak melalui suatu perjanjian. Sedangkan penipuan adalah perbuatan yang dilakukan secara melawan hukum terhadap harta kekayaan seseorang.

Dengan dicantumkannya ketentuan seperti termuat dalam Pasal 1 ayat (1) KUHP, maka barang siapa yang terbukti telah melanggar suatu ketentuan pidana, secara formal perbuatan dimaksud adalah melawan hukum karena perbuatan termaksud telah melanggar suatu larangan yang dicantumkan dalam Undang-Undang Pidana $^{61}$. Sedangkan Hamel yang dikutip oleh R.Achmad S. Soema berpendapat sifat melawan hukum dari suatu delik merupakan salah satu bagian dari pengertian umum dari tindak pidana sehingga menurut pendapatnya, dalam hal dimaksud itu tida dimuat dalam rumusan delik, bagian tersebut dianggap selalu ada ${ }^{62}$.

Lewat pengertian di atas, dapat dicermati "secara melawan hukum" yang dimaksud

${ }^{61}$ R.Achmad S.Soema di Pradja. Pengertian serta sifatnya melawan hukum bagi terjadinya tindak pidana, Armico, Bandung. 1983, h. 23

${ }_{62}$ Ibid, h. 27 
Media Komunikasi dan Informasi Hukum dan Masyarakat

dalam Pasal 378 KUHP secara konkrit ditandai dengan memakai nama palsu atau martabat palsu, dengan tipu muslihat, ataupun rangkaian kebohongan , menggerakkan orang lain untuk menyerahkan barang sesuatu kepadanya, atau supaya memberi utang maupun menghapuskan piutang.

3. Wanprestasi dilatarbelakangi oleh prinsip iktikad baik. Artinya debitor memiliki upaya untuk memenuhi prestasi sesuai apa yang diperjanjikan walaupun dalam pelaksanaannya berakhir pada prestasi buruk. Pasal 1338 point ke 3 yang menyatakan :"Suatu perjanjian harus dilaksanakan dengan iktikad baik."Sedangkan pada penipuan, dilatarbelakangi perbuatan jahat (mensrea) hal ini dapat dilihat dari unsur subjektif tindak pidana penipuan,yaitu : dengan maksud menguntungkan diri sendiri atau orang lain terdapat unsur kesengajaan (dolus/opzet), tidak dalam bentuk ketidaksengajaan.

\section{Bentuk Pertanggungjawaban Wanprestasi dan Penipuan.}

Hukum secara garis besar dibuat untuk mengatur kehidupan yang ada di masyarakat. Kansilmengutip pendapat J.C.T.Simorangkir dan Woerjono Sastropranoto yang menyatakan bahwa hukum adalah peraturan-peraturan yang bersifat memaksa, yang menentukan tingkah laku manusia dalam lingkungan masyarakat yang dibuat oleh badan-badan resmi yang berwajib. Pelanggaran mana terhadap peraturan-peraturan tadi berakibatkan diambilnya tindakan, yaitu dengan hukuman tertentu. ${ }^{63}$ Dapat diambil kesimpulan dari definisi di atas, bahwa pertanggungjawaban dalam bentuk sanksi dibebankan kepada siapa saja yang melanggar perbuatan yang telah ada pengaturannya.

Suatu perbuatan dikatakan sebagai perbuatan hukum apabila perbuatan tersebut mempunyai akibat hukum. Oleh karenanya, suatu perbuatan hukum mempunyai konsekuensi pertanggungjawaban hukum. Berbicara persoalan pertanggungjawaban terkait pembahasan tulisan ini, maka wanprestasi dan penipuan termasuk perbuatan yang telah diatur dalam peraturan perundangundangan, yang apabila dilanggar keduanya memiliki sanksi bagi pelanggarnya.

Sanksi terhadap suatu peristiwa hukum yang dilakukan oleh seseorang digantungkan dari jenis perbuatan hukumnya dan bidang hukum yang mengaturnya. Penulisan ini akan membatasi analisis terkait dengan sanksi di bidang hukum perdata khususnya mengenai wanprestasi dan sanksi tindak pidana penipuan.

Pelanggaran terhadap suatu peristiwa pidana dapat dijatuhkan hukuman sesuai dengan bentuk kesalahan dari pelakunya. Jenis sanksi terhadap pelanggaran suatu peristiwa pidana ditentukan di dalam Pasal 10 KUHP yaitu :

\section{Pidana Pokok}
a. Pidana mati;
b. Pidana penjara;
C. Pidana kurungan;
d. Pidana denda;
e. Pidana tutupan.

2. Hukum Pidana Tambahan

${ }^{63}$ C.ST.Kansil, Pengantar IImu Hukum, Balai Pustaka, Jakarta, 2002, h. 8 
Media Komunikasi dan Informasi Hukum dan Masyarakat

a. Pencabutan hak-hak tertentu;

b. Perampasan barang-barang tertentu;

c. Pengumunan putusan hakim.

Mengingat karya ilmiah ini meneliti perbuatan wanprestasi dan tindak pidana penipuan dimana kedua perbuatan yang berasal dari lapangan hukum yang berbeda, maka sudah tentu pula bentuk pertanggungjawabannya juga berbeda. Untuk mengetahui bentuk pertanggungjawaban dari wanprestasi dan penipuan, akan lebih baik jika terlebih dahulu dibahas mengenai masingmasing bentuk pertanggungjawaban atau sanksi yang akan dikonsentrasikan pada sanksi hukum pidana dan sanksi hukum perdata.

Dalam hukum Pidana, sanksi hukum disebut hukuman. Menurut R. Soesilo, hukuman adalah : "suatu perasaan tidak enak (sengsara) yang dijatuhkan oleh hakim dengan vonis kepada orang yang telah melanggar undangundang hukum pidana." 64

Bagi pelangar Pasal $378 \mathrm{KUHP}$ atau tindak pidana penipuan ditetagaskan sanksi yang dapat diberikan bagi pelaku tindak pidana penipuan adalah pidana penjara paling lama empat tahun. Sanksi terhadap pelaku tindak pidana peniluan secara mutlak adalah sanksi pidana penjara tidak ada sanksi alternatif berupa denda sebagaimana misalnya Pasal 379 KUHP yang mengatakan: Perbuatan yang dirumuskan dalam Pasal 378 KUHP, jika barang yang diserahkan itu bukan ternak dan harga daripada barang, utang atau piutang itu tidak lebih dari dua puluh lima rupiah, diancam sebagai penipuan ringan dengan pidana penjara paling lama 3 bulan atau pidana denda paling banyak dua ratus lima puluh rupiah.

${ }^{64} \mathrm{R}$.Soesilo, Kitab Undang- Undang Hukum Pidana serta Komentar-Komentarnya lengkap dengan Pasal demi Pasal, PT.Gita Karya, Jakarta, h. 30
Apabila hakim memeriksa, mengadili dan memutus suatu perkara pidana penipuan, hakim berdasarkan bukti-bukti yang sah dan berdasarkan keyakinannya terdakwa terbukti secara sah dan meyakinkan telah melanggar ketentuan Pasal 378 KUHP, maka hakim dalam putusannya akan memberikan sanksi hukuman penjara yang dalam praktiknya jarang sekali dikenakan sanksi maksimal sebagaimana ditentukan dalam Pasal 378 KUHP.

Apabila terdakwa menerima putusan hakim maka terdakwa berubah statusnya menjadi narapidana dan dia menjalami hukuman penjara di lembaga Pemasyarakatan yang dijalaninya selama waktu yang ditentukan hakim dalam putusannya. Menjalani hukuman dipenjara adalah bentuk pertanggungjawaban pelaku tindak pidana dengan konsekuensi kebebasannya dirampas untuk jangka waktu yang telah ditentukan oleh hakim karena ia telah melakukan penipuan melanggar Pasal 378 KUHP. Jadi bentuk pertanggungjawaban terhadap pelaku terbukti melanggar tindak pidana penipuan adalah perampasan kebebasan dan menjalaninya di Lembaga Pemasyarakatan.

Oleh karena penipuan berbeda dengan wanprestasi, di mana masing-masing perbuatan yang berasal dari lapangan hukum yang berbeda, maka sudah tentu pula bentuk pertanggungjawabannya juga berbeda. Bentuk pertanggungjawaban dari wanprestasi sebagai dan penipuan, akan lebih baik jika terlebih dahulu dibahas mengenai bagian dari hukum perdata, untuk melihat bentuk pertanggungjawabannya dapat dilihat dari putusan hakim. Adapun sanksi dalam hukum perdata dapat dilihat dari jenis putusan hakim yang membedakan putusan dalam 3 jenis, yaitu 
Media Komunikasi dan Informasi Hukum dan Masyarakat

1. Putusan condemnatoir, yaitu putusan yang bersifat menghukum. Hukuman dalam perkara perdata berlainan dengan hukuman dalam perkara pidana. Dalam perkara perdata, hukuman artinya kewajiban untuk memenuhi prestasi yang dibebankan oleh hakim 65 .

Prestasi itu dapat berwujud memberi (geven, give), berbuat sesuatu (doen, do), atau tidak berbuat sesuatu (niet doen, not do).

2. Putusan declatoir, adalah putusan yang bersifat menyatakan hukum, atu menegaskan suatu keadaan hukum hukum tertentu yang dimohonkan itu ada atau tidak ada. ${ }^{66}$ Putusan declatoir bersifat penetapan saja tentang keadaan hukum, tidak bersifat mengadili, karena tidak ada sengketa. ${ }^{67}$

3. Putusan constituef

Putusan constitutief adalah putusan yang bersifat menghentikan atau menimbulkan keadaan hukum baru. Dalam putusan ini suatu keadaan hukum tertentu dihentikan atau ditimbulkan suatu keadaan hukum baru. 68 Misalnya, putusan pembatalan perkawinan.

Dari uraian di atas dapat disimpulkan bahwa sanksi dalam hukum perdata adalah :

a. Kewajiban untuk memenuhi prestasi

b. Ganti kerugian

c. Hilangnya suatu keadaan hukum, yang diikuti dengan terciptanya suatu keadaan hukum yang baru.

Bentuk pertanggungjawaban dari pelaku wanprestasi biasanya diberikan oleh hakim berdasarkan apa yang dituntut pihak kreditor.

${ }^{65}$ Abdulkadir Muhammad, Hukum Acara Perdata Indonesia, Alumni, Bandung, 1978, h. 167

${ }^{66} /$ bid, h. 168

${ }^{67} \mathrm{Ibid}$

${ }^{68}$ Ibid, h. 169
Pihak kreditor biasanya mengajukan gugatan yang pada petitumnya mengikuti ketentuan Pasal Pasal 1239 KUHPerdata yang menyatakan bahwa : "Tiap-tiap perikatan untuk berbuat sesuatu, atau tidak berbuat sesuatu, apabila si berutang tidak memenuhi kewajibannya, mendapatkan penyelesaiannya dalam kewajiban memberikan penggantian biaya, rugi dan bunga." Selain itu juga dipakai Pasal 1243 KUHPerdata sebagai dasar meminta bentuk pertanggungaban pelaku wanprestasi berupa penggantian biaya, rugi dan bunga diwajibkan kepada si berutang karena tidak terpenuhinya suatu perikatan. Artinya, dalam perkara ingkar janji atau wanprestasi menjadi mutlak bentuk pertanggungjawabannya dengan pemenuhan prestasi atau ganti kerugian biasanya dalam bentuk pembayaran kekayaan atau melakukan suatu perbuatan tertentu.

Pertanggungjawaban pelaku wanprestasi sebatas melakukan sesuatu atau membayar sesuatu dengan kekayaan atau sesuatu yang dapat dinilai dengan uang, tidak dapat dimintai pertanggungjawaban dalam bentuk merampas kebebasan dari pelaku wanprestasi. Hal initegas dinyatakan dalam UU pengesahanICCPR dalam Pasal 11 dinyatakanbahwa tidak seorangpun boleh dipenjarakan hanya atas dasar ketidakmampuannya memenuhi kewajiban kontraktualnya.

Ketentuan Pasal 11 UU pengesahan ICCPR tersebut, senada dengan Pasal 19 ayat (2) UUHAM yang mengatakan : "Tidak seorangpun atas putusan pengadilan boleh dipidana penjara atau kurungan berdasarkan atas alasan ketidakmampuan untuk memenuhi suatu kewajiban dalam perjanjian utangpiutang". 
Media Komunikasi dan Informasi Hukum dan Masyarakat

Oleh sebab itu jelaslah bahwasanya setiap prestasi yang tidak terpenuhi dalam suatu perjanjian, tidak dapat dipidana karenanya. Melainkan dengan cara ganti kerugian sesuai dengan bentuk pertanggungjawaban yang ada di dalam Hukum Perdata.

Pertanggungjawaban wanprestasi dan penipuan mempunyai koridornya masingmasing sehingga dapat dibedakan dengan jelas bentuk pertanggungjawabannya.Pemahaman karakteristik antara wanprestasi dan penipuan sangat penting untuk diketahui terutama oleh para penegak hukum di Indonesia agar tercapainya kepastian hukum. Sebab, apabila kurangnya pemahaman karakteristik antara wanprestasi dan penipuan, disamping tidak tercapainya tujuan hukum, hal ini juga menyangkut hak asasi manusia. Seseorang akan terenggut kebebasannya jika para penegak hukum salah dalam mengambil keputusannya.

Mengutip satu adagium hukum terkenal yang selaras dengan dengan karya ilmiah ini :

"Lebih baik membebaskan 1000 orang yang bersalah daripada menghukum satu orang yang tidak bersalah".

\section{KESIMPULAN DAN SARAN}

\section{A. Kesimpulan}

1. Bahwa, wanprestasi adalah perbuatan ingkar janji atau tidak memenuhinya suatu prestasi dan merupakan bagian dari lingkungan hukum perdata. Sedangkan penipuan merupakan perbuatan dalam lingkungan hukum pidana, dimana perbuatan curang dilakukan dengan maksud memperoleh keuntungan secara sepihak.

2. Faktor penentu antara wanprestasi dan penipuan adalah: a. Wanprestasi timbul akibat perjanjian yang dibuat secara sah. Sedangkan dalam penipuan, kesepakatan yang ditutup dalam suatu kontrak/perjanjian yang disepakati mengalami cacat kehendak.

b. Wanprestasi merupakan tindakan melawan perikatan. Sedangkan penipuan adalah perbuatan yang dilakukan secara melawan hukum.

c. Wanprestasi dilatarbelakangi oleh prinsip iktikad baik.. Sedangkan pada penipuan, tidak ada upaya iktikad baik yang dilakukan.

3. Bentuk pertanggungjawaban Wanprestasi dan Penipuan adalah:

Wanprestasi merupakan bagian dari hukum perdata, dimana bentuk pertanggungjawabannya adalah berupa ganti kerugian, Sedangkan dalam penipuan, sesuai dengan karakteristik sanksi dalam pidana, bentuk pertanggungjawaban yang dikenakan berupa hukuman penjara.

\section{B. Saran}

1. Advokat atau kuasa hukum sebagai pendamping klien atau pihak-pihak awam yang bersengketa dalam hal perjanjian, diharapkan tidak gegabah dengan mengutamakan jalur pidana dalam penyelesaian perkara yang berkaitan dengan perjanjian tanpa melihat duduk perkara secara substansial.

2. Hakim dalam menjatuhkan hukuman yang berkaitan dengan masalah perjanjian, ada baiknya melihat terlebih dahulu perbuatan yang dilakukan secara substansial khususnya pada mengenai wanprestasi dan penipuan. 
Media Komunikasi dan Informasi Hukum dan Masyarakat

3. Setiap orang yang ingin melakukan perjanjian, ada baiknya terlebih dahulu mengetahui konsep dasar perjanjian secara hukum, agar tidak terjadi kerancuan dalam membedakan wanprestasi dan penipuan.

\section{Daftar Bacaan}

\section{A.Buku}

Abdulkadir Muhammad, Hukum Acara Perdata Indonesia, Alumni, Bandung, 1978.

Achmad Ihsan, Hukum Perdata PT.Pembimbing Masa, Jakarta, 1967,

Adami Chazawi. Kejahatan terhadap harta benda. Media nusantara creative, Malang. 2004.

Agus Yudha Hernoko, Asas Proporsionalitas Dalam Kontrak Komersial, Laksbag Mediatama, Yogyakarta, 2008

Bambang Poernomo, Asas-Asas Hukum Pidana, Ghalia Indonesia, Yogyakarta, 1985.

C.ST.Kansil, Pengantar IImu Hukum, Balai Pustaka, Jakarta, 2002.

F.A.F Lamintang, Theo Lamintang, Pembahasan KUHAP menurut IImu Pengetahuan Hukum Pidana dan Jurisprudensi, Jakarta: Sinar Grafika, 2010

H.Mashdui, et.all, Pengertian-Pengertian Elementer Hukum Perjanjian Perdata.CV. Mandar Maju, Bandung, 2001.

Hardijan Rusli. Hukum Perjanjian Indonesia dan Common Law. Pustaka Sinar Harapan, Jakarta, 1993.

Jacob Hans Niewenhuis, Pokok-Pokok Hukum

Perikatan (Terjemahan Djasadin

Saragih), Surabaya,
Komariah Emong Sapardjaja, Ajaran Sifat Melawan Hukum Materil Dalam Hukum Pidana Indonesia, Alumni, Bandung, 2002.

M.Yahya Harahap, Segi-Segi Hukum Perjanjian, Alumni, Bandung, 1986,

Mariam Darus Badrulzaman, Asas-Asas Hukum Perikatan, FH USU, Medan, 1970

Nindyo Pramono, Hukum Komersil, Pusat Penerbitan UT, Jakarta; 2003,

P.A.F.Lamintang, Dasar-Dasar Hukum Pidana Indonesia, Citra Aditya Bakti, Bandung, 1997.

R.Achmad S.Soema di Pradja. Pengertian serta sifatnya melawan hukum bagi terjadinya tindak pidana, Armico, Bandung. 1983.

R.Setiawan, Pokok-Pokok Hukum Perjanjian, Putra Abadin, Jakarta, 1999,

R.Soesilo, Kitab Undang- Undang Hukum Pidana serta Komentar-Komentarnya lengkap dengan Pasal demi Pasal, PT.Gita Karya, Jakarta,1976.

Ridwan Khairandy, Iktikad Baik dalam Kebebasan Berkontrak, Universitas Indonesia, Fakultas Hukum, Pascasarjana, Jakarta, 2003

Ridwan Syahrani, Seluk Beluk dan Asas-Asas Hukum Perdata, Bandung, 1992.

Satochid-Kartanegara, Kumpulan Kuliah Hukum Pidana dan Pendapatpendapat para Ahli Hukum Terkemuka Bagian satu, Balai Lektur Mahasiswa, Jakarta,

Soedjono Dirdjosisworo, Misteri dibalik Kontrak Bermasalah, Mandar Maju, Bandung, 2002,

Subekti, Hukum Perjanjian, Intermasa, Jakarta, 2005 
Media Komunikasi dan Informasi Hukum dan Masyarakat

Subekti, Pokok-Pokok Hukum Perdata, PT Intermasa, Jakarta, 1980,

Taryana Soenandar, et.all Kompilasi Hukum

Perikatan PT.Citra Aditya Bakti,

Bandung 2016. hlm 65

Wiryono Prodjodikoro, Tindak Pidana Tertentu

di Indonesia, Eresco DjakartaBandung, 1967.

Yahman, Karakteristik Wanprestasi \& Tindak

Pidana Penipuan yang lahir dari Hubungan

Kontraktual,

Prenadamedia Group, Jakarta 2014,

Zulfirman, Hak Dasar Manusia Dalam Kontrak dan Perlindungannya di Indonesia, Intelegensia, Malang, 2017.

\section{B.Jurnal}

Zulfirman, Kontrak sebagai sarana mewujudkan Kesejahteraan Sosial, Jurnal Rechtsvinding, Vol.6, No 3, (Desember 2017).

Zulfirman, Hak Dasar Manusia Dalam Hukum Kontrak Indonesia: Analisis Kritis Syarat Kontrak, Jurnal De Jure, Vol. 7, Nomor 2, Juni 2017

\section{C.Kamus}

Departemen Pendidikan dan Kebudayaan, Kamus Besar Bahasa Indonesia, Jakarta 1988

\section{C.Undang-Undang}

Kitab Undang-Undang Hukum Perdata

Kitab Undang-Undang Hukum Pidana

Undang-Undang No.12 Tahun 2005 tentang

pengesahan International Convenant Civil and

Political Right.

Undang-Undang No.39 Tahun 1999 tentang

Hak Asasi Manusia

\section{D.Putusan Pengadilan}

Putusan Mahkamah Agung RI No.

449K/Pid/2001

Putusan Mahkamah Agung RI No.2674

$\mathrm{K} / \mathrm{Pid} / 2006$

Putusan Tingkat Pertama Pengadilan Negeri Jakarta Pusat dalam putusan Nomor : 1782/Pid.B/2004/PN.JKT PST 